\author{
mgr Katarzyna WIŃSKA-RUŻEWICZ \\ absolwentka studiów doktoranckich na Uniwersytecie Gdańskim \\ dr Mariusz ZABOROWSKI \\ Wydział Zarządzania i Ekonomii, Politechnika Gdańska \\ mza@zie.pg.gda.pl
}

DOI: $10.15290 /$ oes.2018.01.91.04

\title{
SPOŁECZNE ZAMÓWIENIA PUBLICZNE
}

\begin{abstract}
Streszczenie
Cel - Zamówienia publiczne, to umowy odpłatne zawierane między zamawiającym a wykonawca, które dotyczą dostaw, usług i robót budowlanych. W artykule przedstawiono pojęcie i genezę społecznych zamówień publicznych, ich rozwój w polskim systemie zamówień publicznych oraz wykorzystywanie klauzul społecznych przez zamawiajacych

Metodologia badań - Dokonano przeglądu literatury przedmiotu oraz wykorzystano analizę przepisów prawa. Jednocześnie przeprowadzono częściową analizę wykorzystywania klauzul społecznych oparając się na raporcie NIK.

Wynik - Podkreślono, powołując się na dane z przeprowadzonej kontroli przez NIK, że promowanie społecznych zamówień nie przynosi pożądanych rezultatów.

Oryginalność/Wartość - Społeczne zamówienia publiczne istotnie moga wpływać na przedsiębiorców, którzy zatrudniają osoby niepełnosprawne, czy też zatrudniających osoby będące członkami grup społecznie marginalizowanych.
\end{abstract}

Słowa kluczowe: zamówienie publiczne, klauzule społeczne, społeczne zamówienia publiczne

\section{SOCIAL PUBLIC PROCUREMENT}

\section{Summary}

Goal - Public contracts are contracts for consideration concluded between the purchaser and the contractor, that apply to the supply, services, and construction work. The article presents the concept and genesis of social public procurement, their development in the Polish public procurement system and the use of social clauses by awarding entities.

Research methodology - The literature has been reviewed and the analysis of legal provisions was used. At the same time, a partial analysis of the use of social clauses was carried out based on the NIK report.

Score - It was emphasized that promoting social orders does not bring the desired results to date.

Originality /value - Social public procurement can significantly affect entrepreneurs who employ people with disabilities or employ people who are members of socially marginalized groups.

Key words: Public contracts, social clauses, public procurement, social

JEL classification: H76, H57, J48 


\section{Wstęp}

Zamówienia publiczne to umowy odpłatne zawierane między zamawiającym a wykonawca, których przedmiotem są dostawy, usługi, roboty budowlane. Odstępując od cytowania przepisów prawa, jednocześnie systematyzując zamawiających, można dokonać podziału na sektor podmiotów publicznych oraz sektor użyteczności publicznej [A. Sołtysińska, H. Talago-Sławoj, 2016, s. 18]. Ważne jest również podkreślenie dualizmu funkcji państwa, gdzie podmioty uczestniczą w rynku jako nabywcy, a jednocześnie reguluja go przez wykorzystanie swojej siły nabywczej, aby realizować przyjęte cele, w tym również społeczne [McCrudden, 2004].

Analizując wpływ systemu zamówień publicznych na zachowanie podmiotów na rynku, należy podkreślić, że zamówienia publiczne ściśle wiążą się z pojęciem przedsiębiorczości, które najczęściej definiuje się jako zespół cech charakteru właściwych przede wszystkim przedsiębiorcom. Głównie do cech tych zalicza się: umiejętność dostrzegania potrzeb i doskonalenia pomysłów, zdolności do wykorzystywania nadarzających się okazji oraz gotowość do podejmowania ryzyka. Tym samym podejmując tematykę zamówień publicznych i uczestnictwa przedsiębiorcy w rynku zamówień publicznych, nie sposób nie przypisać cech przedsiębiorczych przedsiębiorcom, uczestniczącym w rynku zamówień publicznych. Ma to jeszcze większe znaczenie w przypadku przedsiębiorców prowadzących zakłady pracy chronionej, a także innych wykonawców, których działalność, lub działalność ich wyodrębnionych organizacyjnie jednostek, obejmuje społeczną i zawodową integrację osób będących członkami grup społecznie marginalizowanych, które decydują się na uczestnictwo w rynku zamówień publicznych i akceptuja mechanizmy tam panujące. Jak podkreśla A. Sołtysińska i H. Talago-Sławoj, przedsiębiorstwa zatrudniające niepełnosprawnych czy też zakłady pracy chronionej, mogą nie być zdolne do uzyskania zamówienia w normalnych warunkach konkurencji. Dlatego też istotne jest, aby umożliwić zastrzeżenie udziału w niniejszych procedurach zakładom pracy chronionej, podmiotom realizującym założenia polityki społecznej, co ma swoje miejsce $\mathrm{w}$ przepisach prawa unijnego, jak i krajowego [A. Sołtysińska, H. Talago-Sławoj, 2016].

Z rynkiem dóbr i usług wiąże się mechanizm konkurencji, który zależy od stopnia konkurencyjności i przejrzystości rynku. Reguły rynku zamówień publicznych w Polsce są zbieżne w dużej mierze z regułami rynkowymi poza sektorem zamówień publicznych, jednakże można wskazać odrębności właściwe dla rynku zamówień publicznych. W pierwszej kolejności odrębność ta ma swoje miejsce w regułach dotyczących wyboru kontrahenta, gdzie wybór dokonywany jest w oparciu o skonkretyzowane tryby udzielania zamówień publicznych, jak i ograniczenia swobody kontraktowania. Ograniczenie swobody kontraktowania dotyczy sfery wyboru kontrahenta, treści zobowiązania, a służą one zachowaniu zasad proporcjonalności i przejrzystości, jak i zwiększeniu konkurencji przy udzielaniu zamówień publicznych. Chociaż zamówienia publiczne to obszar prawa cywilnego, podkreślany jest także publicznoprawny wydźwięk zamówień publicznych związany z zapewnieniem dóbr publicznych, jak i wydatkowaniem środków publicznych. 
Jak już zasygnalizowano, system zamówień publicznych wprowadza wymóg dokonania wyboru wykonawcy w sposób zapewniający zachowanie uczciwej konkurencji. Jednak skoncentrowanie, co podkreśla A. Panasiuk, środków finansowych w rękach zamawiających będących ich dysponentami, powoduje stworzenie mechanizmów prawnych, które dają możliwość wymagania od wykonawców zaspokojenia potrzeb zamawiających w kształcie i zakresie, jaki zostanie uznany przez zamawiających za najbardziej pożądany [Panasiuk, 2007, s. 9]. Dlatego też zamawiający, wykorzystując swoją siłę nabywczą do optowania na rzecz towarów i usług, które zapewniają również dobre rezultaty społeczne, mogą w znacznym stopniu przyczynić się do zrównoważonego rozwoju. Przyjęto, iż zamówienia publiczne, z uwagi na ich wartość, wielkość środków publicznych, mogą stać się jednym z filarów polityki zrównoważonego rozwoju i obecnych w niej działań - uogólniając - prospołecznych. Tym samym, chociaż czytelne zdają się przesłanki stworzenia uregulowanego prawnie systemu zamówień publicznych, to dostrzeganie kolejnych aspektów zamówień publicznych i wyznaczanie im również innego celu, niż jedynie nabywanie dóbr i usług, jest uzasadnione zmiennymi w czasie kierunkami rozwoju [Trepte, 2004].

Przedsiębiorcy natomiast, bez względu na otoczenie w jakim przyszło im działać i funkcjonować, winni wykazywać się czujnością, dostrzeganiem potrzeb, ale i nadarzającej się okazji, co w tym przypadku oznacza prowadzenie działalności z uwzględnieniem jej aspektów społecznych, które w swoim założeniu mają hołdować zasadom godnej pracy, warunkom zatrudnienia zgodnym z przepisami prawa, również pomóc osobom bezrobotnym, osobom niepełnosprawnym, czy innym potrzebujacym wsparcia w aktywizacji na rynku pracy. Dlatego podkreślanie aspektów społecznych dokonywanych zakupów, preferowanie rozwiązań prospołecznych związanych z zatrudnianiem osób niepełnosprawnych, bezrobotnych, osadzonych, czy innych osób w trudnej sytuacji na rynku pracy, może korzystnie wpływać na beneficjentów systemu zamówień publicznych i ich działania przedsiębiorcze.

Należy również pamiętać, że w literaturze przedmiotu były i są podnoszone argumenty zarówno za, jak i przeciw wprowadzaniu zastosowania polityki społecznej w zamówieniach publicznych. Największym argumentem za było promowanie pomocy osobom długotrwale bezrobotnym, walki ze społecznym wykluczeniem oraz wsparcia osób niepełnosprawnych. Z drugiej strony takie narzędzie w rękach podmiotów publicznych, może stać się instrumentem zmiany równowagi społecznej. Ponadto narzucenie konieczności spełnienia wymogów w zakresie polityki społecznej może również przekreślić cel liberalizacji sektora publicznego w UE. Podkreślane jest także, że konieczność wypełnienia wskazanych założeń może doprowadzić do powstania sytuacji, w której sektor publiczny będzie płacił znacznie więcej za zamówienia przez dodatkowe lub ukryte koszty związane z realizacja zamówienia według zasad polityki społecznej [Bovis, 1998]. 


\section{Społeczne zamówienia - geneza}

Idea uwzględniania aspektów społecznych w procesie udzielania zamówień przez instytucje publiczne została ukształtowana w głównej mierze na szczeblu UE. Przejawem powyższego są liczne unijne jak i krajowe dokumenty o charakterze strategicznym i programowym, w których zamówienia publiczne zostały wskazane jako jeden $z$ instrumentów służących realizacji celów określonych w tych dokumentach, w tym m.in. efektywniejszemu wykorzystaniu zasobów, minimalizowaniu negatywnego oddziaływania na środowisko, wspieraniu rozwoju innowacji, w tym eko-innowacji, wsparciu polityki zatrudnienia oraz integracji grup społecznie marginalizowanych [Krajowy Plan ..., 2017].

Zachowując przejrzystość merytoryczną i redakcyjna, warto w miejscu tym odnieść się do pojęć związanych z aspektami społecznymi w zamówieniach publicznych, jak i geneza łączenia procesu nabywania dóbr i usług przez - upraszczając instytucje zamawiające sektora publicznego, a realizacją polityki społecznej.

Społeczne zamówienia publiczne (społecznie odpowiedzialne zamówienia publiczne) to zamówienia, w ramach których rozpatrywany jest co najmniej jeden $z$ aspektów społecznych, tj.: możliwość zatrudnienia, godna praca, zgodność z prawami społecznymi i z prawem do pracy, integracja społeczna (w tym m.in. osób niepełnosprawnych), równość szans, dostępność i projektowanie dla wszystkich, uwzględnianie kryteriów zrównoważonego rozwoju, także kwestii etycznego handlu oraz szerszego dobrowolnego przestrzegania zasad społecznej odpowiedzialności biznesu (Corporate Social Responsibility - CSR), przy jednoczesnym uwzględnieniu zasad ujętych w Traktacie o Funkcjonowaniu Unii Europejskiej oraz w dyrektywach dotyczących zamówień publicznych [Luksemburg: Urząd Publikacji Unii Europejskiej, 2011, s. 7-8].

W ramach społecznie odpowiedzialnych zamówień publicznych najczęściej spotykane jest pojęcie tzw. klauzul społecznych, tj. uregulowań prawnych umożliwiających zamawiającym uwzględnienie celów społecznych w warunkach realizacji zamówienia. W tak ścisłym znaczeniu, pojęcie klauzul społecznych odnosi się do klauzul o charakterze społecznym dotyczących dodatkowych warunków realizacji zamówienia, które są określane w sposób wyczerpujący w postanowieniach umowy w sprawie zamówienia publicznego [Ołdak-Bułanowska, 2004, s. 8].

Poszukując genezy objęcia zamówień publicznych postulatem badania i wdrażania niejako ,aspektów społecznych”, podkreślana jest w licznych raportach i analizach systemowych wielkość rynku zamówień publicznych i związana z nią możliwość realizacji, czy też wspierania, zamówieniami publicznymi innych celów - tu niejako zadań publicznych ${ }^{1}$. W ramach prowadzenia postępowania o udzielenie zamówienia publicznego, możliwe jest wsparcie udziału podmiotów z sektora małych i średnich przedsiębiorstw, sprzyjanie nabywaniu produktów innowacyjnych, minimalizowanie oddziaływania zamówienia na środowisko naturalne oraz uwzględ-

1 Wartość rynku zamówień publicznych w roku 2016 wyniosła 107,4 mld zł, (w 2015 - 116,3 mld zł, w roku 2014 - 133,2 mld zł, w roku 2013 - 143,2 mld zł). Liczba zamawiających w roku 2016 wyniosła 35116 (w roku 2015 - 35 641, a w roku 2014 - 36 796), [Sprawozdanie ..., 2017]. 
nianie potrzeby osób znajdujących się w szczególnie niekorzystnej sytuacji społeczno-zawodowej².

Uwzględnienie aspektów społecznych w ramach UE ma swoje miejsce w wielu aktach prawnych $i$ innych kształtujących system zamówień publicznych. Warto w tym miejscu przywołać przede wszystkim Komunikat interpretacyjny Komisji Europejskiej w sprawie możliwości uwzględnienia kwestii społecznych w zamówieniach publicznych [KOM (2001) 566] z 2001 roku. Celem tego komunikatu było wykazanie w odniesieniu do prawa wspólnotowego możliwości zintegrowania aspektów społecznych i zamówień publicznych w najlepszy możliwy sposób i w efekcie przyczynienie się do zrównoważanego rozwoju. Aspekty społeczne w tym przypadku mogą być rozumiane jako środki podjęte w celu zagwarantowania zgodności procedur przetargowych $z$ podstawowymi zasadami i przepisami dotyczącymi niedyskryminacji, równego traktowania np. kobiet i mężczyzn czy z krajowym ustawodawstwem w zakresie polityki społecznej. W komunikacie tym wskazana została możliwość uwzględnienia aspektów społecznych udzielanych zamówień zarówno w opisie przedmiotu zamówienia i warunkach jego realizacji, kryteriów oceny ofert, jak i cech podmiotowych wykonawców.

Kontynuacją wskazanego komunikatu był Komunikat Komisji Odnowiona agenda społeczna: możliwości, dostęp i solidarność w Europie XXI wieku, który był reakcją na zachodzące zmiany społeczno-gospodarcze. To właśnie w nim opracowano odnowioną agendę społeczna, m.in. w celu promowania równości płci, zwalczania różnego rodzaju dyskryminacji oraz wykluczenia społecznego, jak również poprawy warunków pracy [KOM, 2008 412]. Powyższe wpisuje się w strategię „EUROPA 2020” na rzecz inteligentnego i zrównoważonego rozwoju sprzyjającego włączeniu społecznemu [KOM (2010; 2020)] oraz będacych w powiazzaniu $z$ nią inicjatyw przewodnich, wspierajacych m.in. priorytety zrównoważonego rozwoju, tj. gospodarkę efektywniej korzystającą z zasobów bardziej przyjaznych środowisku oraz rozwój sprzyjający włączeniu społecznemu [Ołdak-Bułanowska, 2004].

Brytyjska Agencja Zakupów i Dostaw (NHS) - według informacji Banku Światowego zawartej w projekcie „Przewodnik wdrażania CSR” - zakupami „społecznymi” określa zakupy, w których analizuje się wpływ społeczny wynikający z samego procesu zamówienia, czy też identyfikuje się społeczne obszary zainteresowania w powiązaniu z zamawianym produktem. W praktyce odbywa się to przez opis przedmiotu zamówienia, zastosowanie odpowiednich postanowień umowy, a także: promocję zatrudnienia, poprawę warunków pracy, zatrudnianie osób niepełnosprawnych, przestrzeganie podstawowych standardów pracy określonych w konwencjach Międzynarodowej Organizacji Pracy [Ministerstwo Gospodarki, Departament Rozwoju Gospodarki, Warszawa 2008, s. 100].

Szacuje się, że przedsiębiorcy sektora MSP pozyskują około $45 \%$ kontraktów publicznych o wartości przekraczającej progi unijne, występując w roli wykonawców (konsorcjantów) jak i podwykonawców, http://eur-lex.europa.eu/legal-content/EN/TXT/?uri=COM:2017:572:FIN. 
W literaturze podkreśla się, że niezwykle ważne dla rozwoju społecznych zamówień w Europie było posiedzenie Rady Europejska w Göteborgu (15-16 czerwca 2001 roku), gdzie wskazano ukierunkowanie na wspólny rozwój w aspektach ekonomicznych, społecznych, środowiskowych. Nieobowiązujące już dyrektywy 2004/17/EC1 i 2004/18/EC2, podkreślały możliwość uwzględniania kwestii społecznych, zwłaszcza gdy są one powiązane z przedmiotem zamówienia i są we właściwej proporcji do wymagań zamówienia, a także o ile zachowuje się przestrzeganie zasady zachowania właściwej relacji wartości do ceny oraz równego dostępu dla wszystkich dostawców z UE. Również dyrektywa Parlamentu Europejskiego i Rady 2014/24/UE z dnia 26 lutego 2014 roku w sprawie zamówień publicznych, uchylająca dyrektywę 2004/18/WE [Dyrektywa ..., 2014] podkreśla wagę aspektów społecznych w zamówieniach publicznych i wskazuje narzędzia prospołeczne. Znajdujemy tam: zamówienia zastrzeżone, dla których istotnym działaniem jest umożliwienie państwom członkowskim wspieranie w ramach zamówień publicznych podmiotów prowadzących integrację osób zagrożonych wykluczeniem społecznym poprzez aktywny udział tych osób w rynku pracy „Zatrudnienie i praca stanowią kluczowe elementy gwarantujące wszystkim równe szanse i przyczyniające się do integracji społeczeństwa. W związku z tym zakłady pracy chronionej moga odgrywać istotną rolę. To samo dotyczy innych form społecznej działalności gospodarczej mających głównie na celu wspieranie społecznej i zawodowej integracji lub reintegracji osób niepełnosprawnych i znajdujacych się w niekorzystnej sytuacji, takich jak bezrobotni, członkowie znajdujących się $\mathrm{w}$ niekorzystnej sytuacji mniejszości lub grup winny sposób społecznie marginalizowanych. Takie zakłady lub podmioty gospodarcze moga nie być jednak w stanie uzyskać zamówień w zwykłych warunkach konkurencji. W związku z tym właściwe jest, by państwa członkowskie mogły zastrzegać, że prawo do udziału $\mathrm{w}$ postępowaniach o udzielenie zamówień publicznych lub pewnych ich częściach maja jedynie takie zakłady lub podmioty gospodarcze, bądź też zastrzegać realizację zamówień dla programów zatrudnienia chronionego" [Dyrektywa ..., 2014]. Ponadto, w dyrektywie odnaleźć można społeczny wydźwięk zamówień, tj. ogólnej zasady dotyczącej podjęcia przez państwa członkowskie odpowiednich środków służących zapewnieniu, by przy realizacji zamówień publicznych wykonawcy przestrzegali mających zastosowanie obowiązków m.in. w dziedzinie prawa socjalnego i prawa pracy, ustanowionych w przepisach unijnych, krajowych, układach zbiorowych bądź w przepisach międzynarodowego prawa socjalnego i międzynarodowego prawa pracy.

Również w Polsce dostrzeżono problematykę aspektów społecznych w zamówieniach publicznych. Między innymi znalazło to odzwierciedlenie w Strategii „Sprawne Państwo 2020”, w której wskazano, że urzędy administracji publicznej winny $\mathrm{w}$ zdecydowany sposób położyć nacisk na upowszechnianie rozwiązań prawnych w procedurach przetargowych, wykorzystujących klauzule społeczne. Podobne idee przyświecały Strategii Rozwoju Kapitału Społecznego 2020. To w niej postulowano, aby zadania publiczne niezależnie od tego, czy realizuje je podmiot publiczny, prywatny czy organizacja pozarządowa, były wykonywane na odpowied- 
nim poziomie. Równocześnie sugerowano, aby zwiększyć możliwość wykorzystania zamówień publicznych dla realizacji zadań publicznych, przez organizacje obywatelskie i inne podmioty. Do tego niezbędne jest poszerzenie zakresu klauzul społecznych, które umożliwiaja uwzględnianie aspektów społecznych przy zlecaniu takich zadań. Co istotne, takie działania wymagać miały działań edukacyjnych i upowszechniających dotyczących praktycznego stosowania klauzul społecznych [Strategia Rozwoju ..., 2020, 2013, s. 48-49].

Również w Krajowym Planie Działań w zakresie zrównoważonych zamówień publicznych na lata 2017-2020 ujęto podstawowe regulacje zarówno ustawy Prawo zamówień publicznych jak i innych ustaw oraz aktów prawa unijnego, mające znaczenie w kontekście społecznie odpowiedzialnych zamówień publicznych. Zawarto także w nim podsumowanie działań zrealizowanych w latach 2013-2016 dotyczących poziomu uwzględnienia aspektów społecznych w zamówieniach publicznych w Polsce. Krajowy Plan Działań wpisuje się w realizację celu, jakim jest budowa inteligentnego systemu zamówień publicznych przez działania promocyjnoedukacyjne, ukierunkowane na szersze wykorzystanie w postępowaniach przetargowych m.in. klauzul społecznych. Równocześnie jest dokumentem, na podstawie którego realizowane są inicjatywy służące promowaniu wykorzystywania aspektów społecznych w postępowaniach o udzielenie zamówienia publicznego, do których zobligowany został Prezes Urzędu Zamówień Publicznych przez Radę Ministrów w Zaleceniach Rady Ministrów w sprawie uwzględniania przez administrację rządową aspektów społecznych w zamówieniach publicznych [Krajowy Plan ..., 2017, s. 7-8].

\section{Zamówienia społeczne w ustawie - Prawo zamówień publicznych}

Zamówienia społeczne i ich promowanie, jest również przedmiotem regulacji ustawy Prawo zamówień publicznych. Obecnie w polskim prawie zamówień publicznych obowiązują dwie klauzule społeczne; są to klauzula zastrzeżona i klauzula zatrudnieniowa. Głównym celem zamieszczenia wspomnianych klauzul, jest m. in. aktywizacja osób niepełnosprawnych, bezrobotnych, będących członkami grup społecznie marginalizowanych. Należy jednak wspomnieć, że klauzule społeczne obecne są od roku 2009 w polskim prawie zamówień publicznych i pierwotnie obowiązywały trzy: klauzula zastrzeżona, klauzula zatrudnieniowa oraz klauzula propracownicza $^{3}$. Klauzule te zostały wzmocnione w nowelizacji ustawy - Prawo zamówień publicznych z roku 2014 i w ostatniej nowelizacji z 2016 roku, która wdrożyła dwie dyrektywy unijne, nr 24 i 25, które wprowadzono w art. 22 i 29 wspomnianej ustawy. Zmiany te wynikają wprost z zaleceń zawartych $\mathrm{w}$ prawie europejskim, ale również są odzwierciedleniem proponowanych i pożądanych zmian zgłaszanych przez organizacje pozarządowe. Również Urząd Zamówień Publicznych wskazuje, iż zmiana ustawy Pzp w zakresie aspektów społecznych została

3 Ostatnia propracownicza nie obowiązuje od roku 2014. 
podyktowana nie tylko implementacją dyrektyw zamówieniowych, ale również stanowi reakcję na problem krajowego rynku zamówień publicznych ${ }^{4}$.

Tym samym klauzule społeczne $\mathbf{w}$ prawie zamówień publicznych zostały w sposób znaczący wzmocnione i osiagnęły kształt korzystny dla podmiotów ekonomii społecznej. Jak bardzo skorzystaja na tych zmianach osoby marginalizowane i mające problem $z$ dostępem na rynku pracy, zadecyduja samorządy $i$ inni zamawiający. Należy przy tym podkreślić, że rozwiązania umożliwiające stosowanie aspektów społecznych, klauzul społecznych, przyczyniać się powinny do zwiększenia efektywności wydatkowania środków publicznych, właśnie przez osiagnięcie celów społecznych.

Z obecnie obowiązujących klauzul, pierwsza z nich (zastrzeżona), uregulowana jest w przepisach art. 22 ustawy - Prawo zamówień publicznych i w głównej mierze dotyczy aspektów ekonomii społecznej. Artykuł ten koresponduje z art. 20 Dyrektywy 2014/24/UE. Zasadniczo, klauzula ta pozwala Zamawiającemu ograniczyć krąg podmiotów, które będą mogły ubiegać się o zamówienie publiczne. Istotne zmiany $\mathrm{w}$ przepisach odnoszących się do wspomnianej klauzuli, nastapiły wraz z ostatnią nowelizacja. Nowelizacja z roku 2016 rozszerzyła krag podmiotów i jednocześnie zmniejszyła wymagania odnośnie poziomu zatrudnienia (nie mniej niż $30 \%$ ), co przed wejściem w życie nowelizacji było trudnym wymogiem do spełnienia. Tym samym od momentu obowiązywania znowelizowanej ustawy Prawo zamówień publicznych o udzielenie zamówienia mogą ubiegać się wykonawcy, o ile takie zastrzeżenie wyartykułuje zamawiający, prowadzący wyłącznie zakłady pracy chronionej, a także wykonawcy, których działalność obejmuje społeczną i zawodową integrację osób będących członkami grup społecznie marginalizowanych. Dotyczy to w szczególności następujących grup, aczkolwiek pamiętać należy, że lista ta nie jest katalogiem zamkniętym:

1) osób niepełnosprawnych w rozumieniu ustawy z dnia 27 sierpnia $1997 \mathrm{r}$. o rehabilitacji zawodowej i społecznej oraz zatrudnianiu osób niepełnosprawnych (Dz. U. z 2011 r. poz. 721, z późn. zm. 2);

2) bezrobotnych w rozumieniu ustawy $z$ dnia 20 kwietnia 2004 r. o promocji zatrudnienia i instytucjach rynku pracy (Dz. U. z 2016 r. poz. 645, 691 i 868);

3) osób pozbawionych wolności lub zwalnianych z zakładów karnych, o których mowa w ustawie z dnia 6 czerwca 1997 r. - Kodeks karny wykonawczy (Dz. U. poz. 557, z późn. zm. 3), mających trudności w integracji ze środowiskiem;

4) osób z zaburzeniami psychicznymi w rozumieniu ustawy z dnia 19 sierpnia 1994 r. o ochronie zdrowia psychicznego (Dz. U. z 2016 r. poz. 546);

5) osób bezdomnych w rozumieniu ustawy $z$ dnia 12 marca 2004 r. o pomocy społecznej (Dz. U. z 2015 r. poz. 163, z późn. zm. 4);

4 Materiały Urzędu Zamówień Publicznych udostępnione w ramach działalności edukacyjnej: https://www.uzp.gov.pl/_data/assets/pdf_file/0018/32805/Aspekty-spoleczne-w-zamowieniach publicznych_prawo-krajowe.pdf [data wejścia: 11.05.2017]. 
6) osób, które uzyskały w Rzeczypospolitej Polskiej status uchodźcy lub ochronę uzupełniająca, o których mowa w ustawie z dnia 13 czerwca 2003 r. o udzielaniu cudzoziemcom ochrony na terytorium Rzeczypospolitej Polskiej (Dz. U. z 2012 r. poz. 680, z 2013 r. poz. 1650, z 2014 r. poz. 1004, z 2015 r. poz. 1607 oraz z 2016 r. poz. 783);

7) osób do 30. roku życia oraz po ukończeniu 50. roku życia, posiadających status osoby poszukującej pracy, bez zatrudnienia;

8) osób będących członkami mniejszości znajdującej się w niekorzystnej sytuacji, w szczególności będących członkami mniejszości narodowych i etnicznych w rozumieniu ustawy z dnia 6 stycznia 2005 r. o mniejszościach narodowych i etnicznych oraz o języku regionalnym (Dz. U. z 2015 r. poz. 573 oraz z 2016 r. poz. 749).

Istotne natomiast jest, by minimalny wskaźnik zatrudnienia osób należących do jednej lub więcej kategorii wymienionych, nie był mniejszy niż 30\%, osób zatrudnionych przez zakład pracy chronionej lub wykonawców albo ich jednostek. Transpozycja omawianego art. 20 dyrektywy 2014/UE/24 nie jest obligatoryjna, jednakże w literaturze przedmiotu podkreślana jest rola powyższej klauzuli jako narzędzia wspierania społecznej i profesjonalnej integracji osób niepełnosprawnych i osób w niekorzystnej sytuacji. Wagę powyższej klauzuli potęguje sytuacja, w której istniejące w niektórych państwach członkowskich regulacje wskazujące konieczność podjęcia kroków na rzecz integracji osób niepełnosprawnych, nie przyniosły oczekiwanych rezultatów, gdyż podmioty były skłonne ponosić konsekwencje nieprzestrzegania tych wymogów. ${ }^{5}$

Kolejną klauzulą społeczną obowiazującą w polskim systemie zamówień publicznych, jest klauzula zatrudnieniowa, która również preferuje udzielanie zamówień publicznych podmiotom zatrudniającym osoby o cechach stawiajacych je w trudniejszej sytuacji na rynku pracy, co stanowi swoiste faworyzowanie osób defaworyzowanych. Ważne natomiast jest to, że zamawiający nie mogą ograniczyć udziału wykonawców niemieszczących się w wytycznych klauzuli, co ma miejsce w przypadku udzielenia zamówienia $\mathrm{z}$ wykorzystaniem przepisów odnoszących się do klauzuli zastrzeżonej.

Klauzula zatrudnieniowa opisana jest w art. 29 ust. 4 ustawy - Prawo zamówień publicznych. Klauzula ta nie jest skierowana tak jak klauzula zastrzeżona tylko do wykonawców prowadzących zakłady pracy chronionej oraz inni wykonawców, których działalność, lub działalność ich wyodrębnionych organizacyjnie jednostek, realizują zamówienia, obejmujące społeczną i zawodową integrację osób będących członkami grup społecznie marginalizowanych. Ustawodawca w klauzuli zatrudnieniowej położył nacisk na opis przedmiotu zamówienia, a zwłaszcza wymagania związane $z$ realizacją zamówienia, które mogą obejmować aspekty gospodarcze, środowiskowe, społeczne, związane z innowacyjnością lub zatrudnieniem. Dotyczy to w szczególności zatrudnienia:

5 A Social Platform guide to Public Procurement Directive, http://www.socialplatform.org/. 
1) bezrobotnych w rozumieniu ustawy z dnia 20 kwietnia 2004 r. o promocji zatrudnienia i instytucjach rynku pracy;

2) młodocianych, o których mowa w przepisach prawa pracy, w celu przygotowania zawodowego;

3) osób niepełnosprawnych w rozumieniu ustawy z dnia 27 sierpnia $1997 \mathrm{r}$. o rehabilitacji zawodowej i społecznej oraz zatrudnianiu osób niepełnosprawnych;

4) innych osób niż określone w pkt. 1, 2 lub 3, o których mowa w ustawie z dnia 13 czerwca 2003 r. o zatrudnieniu socjalnym (Dz. U. z 2011 r. poz. 225 i 1211 oraz z 2015 r. poz. 1220 i 1567) lub we właściwych przepisach państw członkowskich Unii Europejskiej lub Europejskiego Obszaru Gospodarczego.

Jak można zauważyć, klauzula ma zdecydowanie szersze zastosowanie niż klauzula zastrzeżona, gdyż krag pomiotów ubiegających się o udzielenie zamówienia z wykorzystaniem przepisów klauzuli zatrudnieniowej, nie ogranicza się tylko do zakładów pracy chronionej, czy też osób niepełnosprawnych. Co istotne, klauzula ta może również być wykorzystywana przy zamówieniach, dotyczących przedmiotu zamówienia i wykonania zamówienia innowacyjnego, które może spowodować integrację osób społecznie marginalizowanych. Nowelizacją ustawy - Prawo zamówień publicznych wprowadzono również, określony w art. 29 ust. 3a ustawy, obowiązek określenia przez zamawiającego w opisie przedmiotu zamówienia w przypadku usług i robót budowlanych czynności, które mają być wykonywane przez osoby zatrudnione na umowę o pracę, jeżeli wykonanie tych czynności polega na świadczeniu pracy w rozumieniu art. 22 par. 1 ustawy z dnia 26 czerwca 1974 r. Kodeks pracy. Zamawiający wskazuje również sposób w jaki będzie kontrolował wypełnienie powyższego obowiązku i sankcje za jego niewypełnienie. Aspekty społeczne zamówień to również dostosowanie nabywanego przedmiotu zamówienia do potrzeb osób niepełnosprawnych - zarówno w przypadku nabywania dóbr na rzecz ogółu społeczeństwa, jak i dla samego zamawiającego w celu realizacji przez niego zadań.

\section{Efektywność wykorzystania klauzul społecznych}

Wykorzystanie klauzul społecznych w zamówieniach publicznych było przedmiotem m.in. badania kontrolnego przeprowadzonego przez NIK. Badaniem objęto okres od 1 stycznia 2013 roku do 30 kwietnia 2016 roku. Celem kontroli była ocena stosowania klauzul społecznych w zamówieniach publicznych udzielanych przez wybrane jednostki administracji publicznej. Badanie wykazało, że wprowadzone klauzule społeczne w roku 2009 w znaczący sposób nie były wykorzystywane przez zamawiających, pomimo pozytywnych działań szefa KPRM oraz Prezesa Urzędu Zamówień Publicznych na rzecz upowszechnienia klauzul społecznych w zamówieniach publicznych administracji rządowej.

Również samorządy w znikomym stopniu korzystały z tego rozwiązania [NIK, 2017]. Najwyższa Izba Kontroli w szczególności skontrolowała: 
- podejmowane działania na rzecz zwiększania skali stosowania klauzul społecznych w zamówieniach publicznych,

- realizacje przez zamawiających jak i wykonujących zamówienia publiczne obowiązków w zakresie planowania i realizacji zamówień uwzględniających klauzule społeczne, a także sposób kontroli i przestrzegania zastosowanych klauzul społecznych,

- $\quad$ efekty stosowania klauzul społecznych w zamówieniach publicznych.

RYSUNEK 1.

Udział umów, w których zastosowano klauzule lub aspekty społeczne w całkowitej liczbie umów zawartych w wyniku udzielenia zamówień w oparciu o Pzp oraz zamówień podprogowych w kontrolowanym okresie

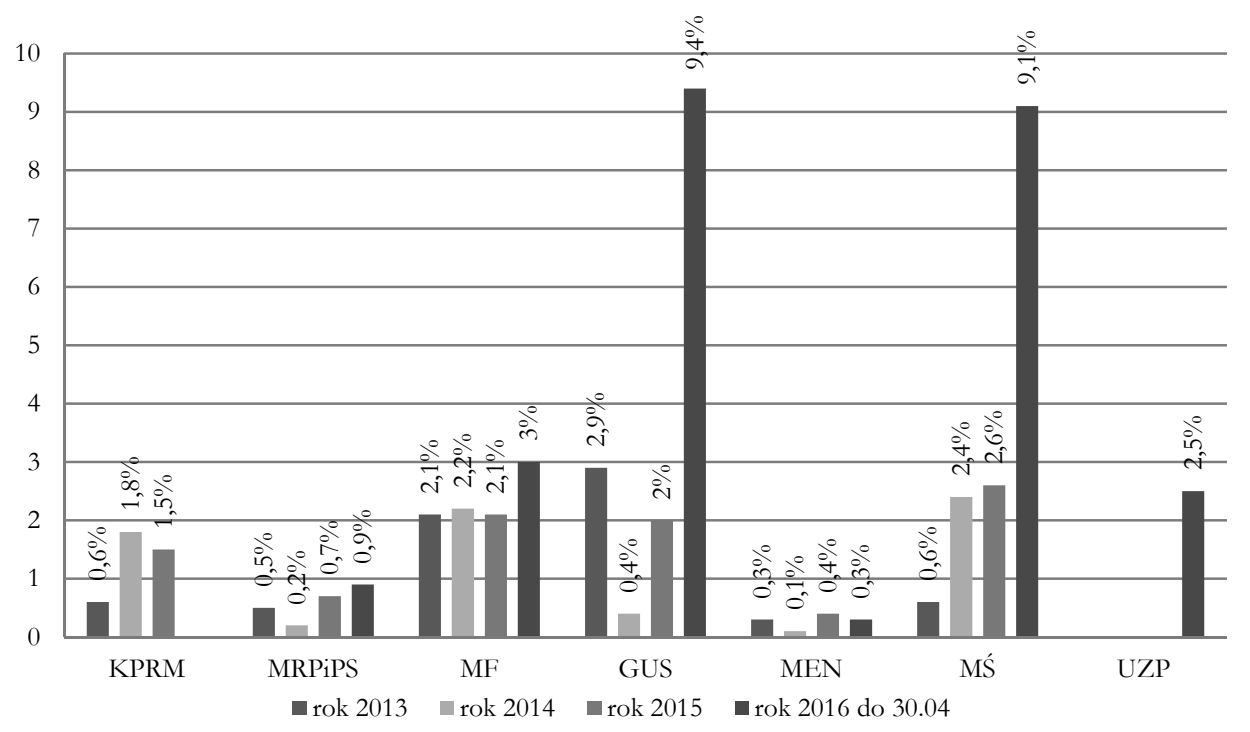

Źródło: Raport NIK.

Do głównych „grzechów” w wykorzystywaniu klauzul społecznych zaliczono w pierwszej kolejności nierzetelne przygotowanie zamówień, brak należytego nadzoru nad realizacją umów w części dotyczącej klauzul społecznych oraz nieprzeprowadzanie analiz racjonalności stosowania tychże klauzul ani ocen społecznych skutków, kosztów i korzyści wynikających z ich zastosowania. Kontroli poddano 29 jednostek, w tym: Kancelarię Prezesa Rady Ministrów, Urząd Zamówień Publicznych, Główny Urząd Statystyczny oraz cztery ministerstwa (Ministerstwo Finansów, Ministerstwo Rozwoju Pracy i Polityki Społecznej, Ministerstwo Edukacji Narodowej i Ministerstwo Środowiska).

Wyniki przeprowadzonej kontroli nie napawają optymizmem. W skontrolowanych jednostkach administracji rządowej, udzielono w kontrolowanym okresie tylko 115 zamówień, o łącznej wartości ponad 247 mln złotych, w których zastoso- 
wano klauzule społeczne bądź aspekty społeczne. Spośród wszystkich umów, które zostały zawarte przez wymienione jednostki, tylko w $0,9 \%$ umów uwzględniono klauzule społeczne, co stanowiło około $17 \%$ całkowitej wartości zawartych umów przez jednostki. Natomiast najwięcej zamówień z wykorzystaniem klauzul społecznych i aspektów społecznych miało swoje miejsce w Ministerstwie Finansów (41), najmniej zaś, w Urzędzie Zamówień Publicznych (1), [NIK, 2017].

RYSUNEK 2.

Udział umów, w ktorych zastosowano klauzule lub aspekty społeczne w wartości umów zawartych w wyniku przeprowadzonego postępowania przetargowego w poszczególnych latach w okresie objętym kontrolą

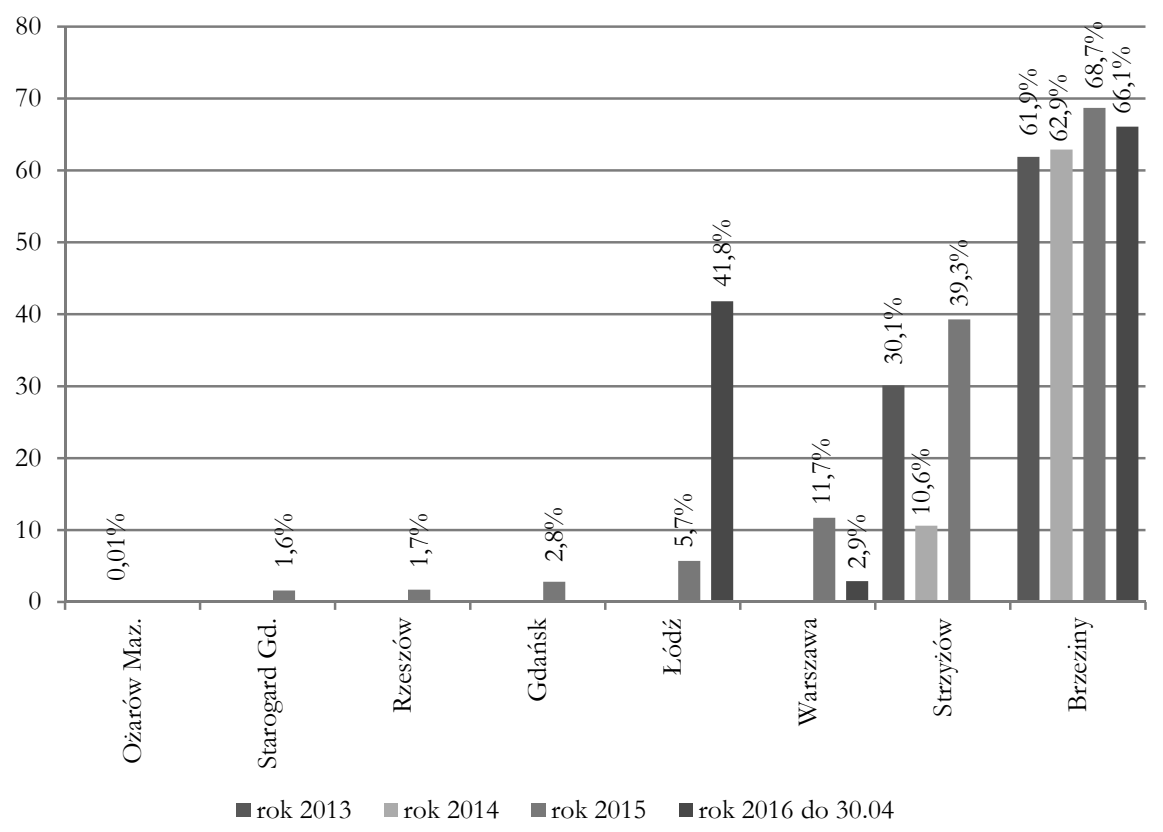

Źródło: Raport NIK.

W przypadku zaś jednostek samorządu terytorialnego, wykorzystywanie aspektów społecznych i klauzul, przedstawiało się w sposób następujący:

W skontrolowanych jednostkach wykazano, że podjęto działania zmierzające do stosowania bądź zwiększenia skali stosowania klauzul społecznych w zamówieniach publicznych. Dotyczyło to w szczególności przeszkolenia pracowników oraz rozpowszechnianiu informacji dotyczacych stosowania klauzul społecznych. Natomiast w dwóch gminach objętych kontrolą (Ożarów Mazowiecki i Starogard Gdański) od dnia wejścia w życie przepisów umożliwiających stosowanie klauzul społecznych, w urzędach tych nie prowadzono działań na rzecz ich wykorzystania w zamówieniach pub- 
licznych. Pomimo tak znikomego wykorzystywania klauzul społecznych, zwrócono uwagę, że niektóre gminy z powodzeniem stosowały klauzule społeczne $\mathrm{w}$ zamówieniach publicznych na szeroką skalę. Dotyczy to zwłaszcza gminy Brzeziny, która z klauzul społecznych uczyniła ważny instrument $\mathrm{w}$ rozwiązywaniu problemów osób znajdujących się w niekorzystnej sytuacji związanej z zatrudnieniem i integracja społeczna. Mimo tego, świadomość wykorzystywania klauzul społecznych, a zwłaszcza ich praktyczne zastosowanie pozostawia wiele do życzenia.

Tym samym w raporcie NIK rekomendowała, aby rozważyć działania promujące korzystanie z tego instrumentu polityki społecznej, m.in. przez zmianę lub modyfikację formuły upowszechniania klauzul i aspektów społecznych, a także eliminowanie barier i trudności związanych z ich stosowaniem. Najwyższa Izba Kontroli zwróciła uwagę, na ciagle zbyt małą aktywizację osób zagrożonych wykluczeniem społecznym. Na podstawie danych GUS w ramach kwartalnych Badań Aktywności Ekonomicznej Ludności (BAEL) można stwierdzić, że współczynnik aktywności zawodowej osób niepełnosprawnych w Polsce w wieku produkcyjnym, wynosił 27,2\% w roku 2014 [Kobus-Ostrowska, 2015, s. 23]. Natomiast w roku 2015 wspólczynnik ten wynosił $25,9 \%$ (w roku $2013-27,3 \%$, w roku $2012-27,5 \%$ ). Dane te na pewno są niepokojące i powinny być impulsem do zwiększenia przez państwo działań zmierzających do aktywizacji osób niepełnosprawnych i wykluczonych społecznie. Dlatego uwzględnienie klauzul społecznych w zamówieniach publicznych, przewidziano w Strategii Sprawne Państwo 2020, Strategii Rozwoju Kapitału Społecznego oraz Krajowym Programie Rozwoju Ekonomii Społecznej, podobnie jak to miało miejsce w Krajowym Planie Działań w zakresie zrównoważonych zamówień publicznych na lata 2013-2016.

\section{Podsumowanie}

Klauzule społeczne mogą i powinny być szansą dla przedsiębiorstw społecznych, które zatrudniają osoby mające szczególne problemy z integracją zawodową i społeczną. Mimo promowania uwzględnienia społecznych kwestii w zamówieniach publicznych, nie przełożyło się to na znaczący wzrost liczby zamówień publicznych realizujących politykę społeczna. Jak się okazuje, promocja ta nie zmieniła w niczym postrzegania klauzul społecznych, które wciąż są mało znane i niewypromowane. Tematyka klauzul społecznych jak do tej pory jest ciagle szansą niewykorzystaną przez zamawiających, o czym świadczy liczba udzielonych zamówień, w których były wykorzystane klauzule społeczne. Jak wskazują dane Urzędu Zamówień Publicznych, w 2013 roku postępowań z klauzulą zastrzeżoną było w całej Polsce 400, co stanowiło nieco ponad dwa promile wszystkich udzielonych zamówień o wartości powyżej 30 tysięcy euro. Podobnie w przypadku klauzuli zatrudnieniowej, która wykorzystano w około 500-600 przypadków w 2013 roku.

Do podobnych wniosków na podstawie przeprowadzonej kontroli doszła NIK, która wykazała, że w latach 2013-2016 (do 30.04.2016) skontrolowane 
jednostki administracji rządowej udzieliły 115 zamówień o łącznej wartości ponad $247 \mathrm{mln}$ zł, w których zastosowano klauzule bądź aspekty społeczne. Zawarte umowy, które uwzględniały klauzule społeczne, stanowiły zaledwie niecały procent $(0,9 \%)$ wszystkich zawartych umów $w$ tym okresie oraz niecałe $17 \%$ ich całkowitej wartości.

Procedury dotyczące zamówień publicznych same w sobie nie należą do prostych i wiąża się z dużą odpowiedzialnością osób przygotowujących i prowadzących procedurę oraz nadzorujących ze strony zamawiającego wykonanie zamówień, to raczej głównym powodem niestosowania przez zamawiających klauzul społecznych jest niechęć do wprowadzania dodatkowych wymogów, które muszą być jasno sformułowane na etapie przygotowania procedury, badane na etapie udzielenia zamówienia i egzekwowane podczas wykonania zamówienia. Równocześnie wykorzystywanie klauzul społecznych jest ciagle spowodowane brakiem świadomości korzyści, jakie wynikają z ich zastosowania, jak również wiedzy na temat prawidłowego określenia wymogów w dokumentacji oraz późniejszego monitorowania przestrzegania zapisów dotyczących klauzul społecznych.

Tym samym niewielkie zastosowanie klauzul społecznych czy uwzględnienie aspektów społecznych i polityki zrównoważonego rozwoju, wynika z stosunkowo niewielkiej wiedzy instytucji zamawiających na temat możliwości stosowania klauzul społecznych w zamówieniach publicznych, na co wskazywałyby również głosy podnoszone podczas różnego rodzaju szkoleń i konferencji. Konieczna jest zatem kontynuacja i wzmocnienie działań edukacyjno-promocyjnych, których celem będzie zwiększenie poziomu uwzględniania klauzul społecznych w postępowaniach o udzielenie zamówienia publicznego.

\section{Literatura}

Bovis Ch., 1998, The Liberalisation of Public Procurement and its Effects on the Common Market, Ashgate Publishing Ltd, Ashgate.

Dyrektywa Parlamentu Europejskiego i Rady 2014/24/UE z dnia 26 lutego 2014 r. w sprawie zamówień publicznych, uchylająca dyrektywę 2004/18/WE.

Kobus-Ostrowska D., 2015, Bierność zawodowa osób niepetnosprawnych w Polsce, [w:] Gospodarka w teorii i praktyce, Instytut Ekonomii, Uniwersytet Lódzki, Łódź.

Komisja Europejska, 2011, Kwestie społeczne w rakupach Przewodnik dotyczacy un agledniania kwestii spotecznych w zamónieniach publicznych, Urząd Publikacji Unii Europejskiej, Luksemburg.

Komisja Europejska, 2010, Strategia „Europa 2020” na rzecz inteligentnego i zrównowa:̇onego Rozpoju sprayjajacego właczeniu spotecznemu, Bruksela.

Komisja Europejska, 2009, Komunikat Komisji Odnowiona agenda spoteczna: możliwości, dostęp i solidarność w Europie XXI wieku, Bruksela.

Komunikat Komisji KOM (2001) 566, Official Journal 333, 28/11/2001 P. 0027 0041, http://eur-lex.europa.eu/legal-content/pl/TXT/?uri=CELEX\%3A52001 DC056. 
Krajony Plan Dziatań w zakresie zrównoważonych zamówień publicznych na lata 2017 2020, 2017, UZP, Warszawa, www.uzp.gov.pl [data wejścia: 21.06.2017].

McCrudden Ch., 2004, Using public procurement to achieve social outcomes, Natural Resources Forum 28.

Ministerstwo Gospodarki, Departament Rozwoju Gospodarki, 2008, Nowe podejście do zamónień publicznych, Warszawa.

Najwyższa Izba Kontroli, 2017, Klauzule społeczne w zamónieniach publicznych udzielanych przez administracje publiczna lata 2013-2016, NIK, Warszawa.

Ołdak-Bułanowska K., 2004, Aspekty społeczne w zamówieniach publicznych - Podrecznik UZP, Warszawa.

Panasiuk A., 2007, Publicznoprawne ograniczenia præy udzielaniu zamónień publicznych, Oficyna Wydawnicza Branta, Bydgoszcz-Warszawa.

Sołtysińska A., Talago-Sławoj H., 2016, Europejskie prawo zamónień publicznych. Komentary, wyd. 3, Wolters Kluwer, Warszawa.

Sprawozdanie Prezesa Urzedu Zamówień Publicznych o funkcjonowaniu systemu zamónień publicznych w Polsce w roku 2016, 2017, Warszawa.

Strategia Rožwoju Kapitatu Społecznego 2020, 2013, Warszawa.

Trepte P., 2004, Regulating Procurement. Understanding the ends and Means of Public Procurement Regulation, Oxford University Press Inc., New York, Preface.

Ustawa z dnia 29 stycznia 2004 r. - Prawo zamówień publicznych (Dz. U. 2017 poz. 1579).

http://eur-lex.europa.eu/legal-content/EN/TXT/?uri=COM:2017:572:FIN [data wejścia: 11.02.2018].

https://www.uzp.gov.pl/_data/assets/pdf_file/0018/32805/Aspekty-spolecznew-zamowieniach-publicznych_prawo-krajowe.pdf [data wejścia: 11.05.2017].

\section{Wkład autorów w powstanie artykułu}

- mgr Katarzyna Wińska-Rużewicz - 50\%

- dr Mariusz Zaborowski - 50\% 